$T$ esassosego

DESASSOSSEGO 20 | DEZ/2018 | ISSN 2175-3180 DOI: http://dx.doi.org/10.11606/issn.2175-3180.v10i20p179-181

\title{
DOIS CANTOS DE MALDIÇÃO E MEMÓRIA
}

Isadora Machado ${ }^{1}$

\section{[moscas vestem o ventre]}

Quis o tempo que restava na pedra - criei o desterro

da fera que sangrou o Moinho. Luz feita por entretantos

da ida, será comestível

ao pássaro

toda gente

que sondar o destino.

Febre feita chaga foi esse seu

modo de abrir los caminos

¿Qual demônio será possuído pela força que meu ventre obriga?

\section{[sonido]}

Lanço-me ao mar febril e indago a este contato

o que nele seria doente. No vazio criado entre

pessoa-pele e eu-esteve-mar, abdico

do rio

do ébrio

das coisas

\footnotetext{
1 Doutora em Linguística pela Unicamp. Professora Adjunto do Departamento de Letras Vernáculas, na
} Universidade Federal da Bahia. 


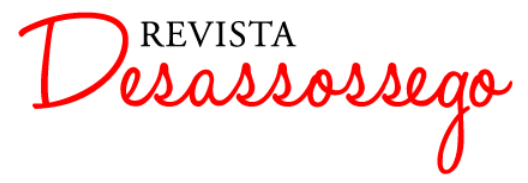

DESASSOSSEGO 20 | DEZ/2018 | ISSN 2175-3180 DOI: http://dx.doi.org/10.11606/issn.2175-3180.v10i20p179-181

Prendo-me ao vento que solfeja teu canto pesaroso.

Canso-me. Canso-me da castidade das gentes, que

$\operatorname{sim}$

são pessoas guardadas

pela sofreguidão das janelas

que também são cinemas

Para pensar no sangue, escuto o ronco oco das manhãs

Véu para a noite que a escuridão sufoca

¡Pirata!_Diablo Mouro! ¡Viejito!

Devolvi à terra oito crianças

e mais nenhum sacrilégio te fará volver

Nem a vingança que é um caminho,

pois esquinas só os em-fuga abrigam

Derramo meu canto na cruz das ruas

E te peço de volta. Mas não, nada.

Deitarei aos pés do cajazeiro.

Ah, Velho Teseu, teço daqui e me rio de ti e de mim!

Habitada pelas heras donde me deito

Avisto las mujeres-pájaros.

- Hechiceras de la palabra, 


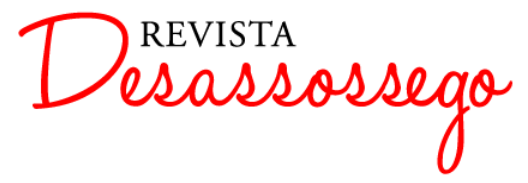

DESASSOSSEGO 20 | DEZ/2018 | ISSN 2175-3180 DOI: http://dx.doi.org/10.11606/issn.2175-3180.v10i20p179-181

estoy embrujada por él y

no sé qué hacer. Te pido

que ¡escuchen las zarabandas!

Elas estavam reinando soberanas na copa

disseram pra dizer quando passassem

que nunca na meia-noite alguém estivesse

desprotegido por ele que nelas reina soberano olho

e rezasse oito vezes a reza e cantasse e dançasse

e sem medo voasse: afoguei a palavra em lágrima

pedaço do mar que me cabe derramar no rio

$\mathrm{E}$ assim me enamorei daquelas pedras

que corriam cascatas no banho das meninas virgens

Eu versejei a pedra

Meu grande pássaro desabitado. 